\title{
An Economic Analysis of Production and Marketing of Ginger in Bilaspur District of Chhattisgarh, India
}

\author{
Dilip Kumar Sonwani $^{1 *}$, A.K. Koshta ${ }^{1}$ and Birendra Tigga ${ }^{2}$ \\ ${ }^{1}$ Department of Agricultural Economics, Indira Gandhi Krishi Vishwavidyalaya, \\ Raipur 492012 (CG), India \\ ${ }^{2}$ Department of Agricultural Agronomy, Indira Gandhi Krishi Vishwavidyalaya, \\ Raipur 492012 (CG), India \\ *Corresponding author
}

\section{A B S T R A C T}

This study seeks to examine (i) the growth rate in area, production and productivity of ginger in Bilaspur district and Chhattisgarh State, (ii) costs and returns of ginger, (iii) disposal pattern of ginger in the study area and (iv) the major constraints in production and

\section{Keywords}

Ginger, Growth rate, Cost and returns, Input output ratio, Yield and profitability,

Marketing, Disposal pattern, Constraints

Article Info

Accepted: 16 December 2017 Available Online: 10 January 2018 marketing of spices and suggest suitable measures to overcome them. The study was conducted in Gaurella and Pendra blocks of Bilaspur district of Chhattisgarh state. Total 50 farmers were considered for the study, which comprised of small (25), medium (20) and large (5). The Primary data were collected from the sample farmers through personal interview method. The data were pertaining for agricultural. The study envisaged that family size of sample farmers was 5.8 members. The average farm size was found to be 2.21 hectares. Overall cropping intensity was observed to be 184 percent. The average cost of cultivation of ginger was Rs/ha. 106368 and estimated gross return was Rs/ha 392123 . The cost per quintal production of ginger was noticed to be Rs 983 . The average yield of ginger was q $109 \mathrm{q} / \mathrm{ha}$. The benefit cost ratio of ginger was registered to 1:2.67. There were two marketing channels for marketing of spices, viz., Channel-I: Producer Consumer and Channel-II: Producer - Itinerant trader - Consumer. Among the sample ginger growers more than ninety five percent marketable surpluses were observed in ginger. The major constraints pertaining to cultivation of ginger were higher cost of labour, price of seed and fertilizer. Major constraints in marketing of ginger lack of storage facility, standardization and grading at grower level in the study hence, there is a need to bring mechanization in the production and post-harvest management of ginger.

\section{Introduction}

There are 107 spices with 20 countries being involved in the production and Export (India 50 spices). During 2013-14 India produced 5908.00 metric tons of spices (Indian Horticulture Database-2014). Indian spices flavor foods in over 134 countries, spice exports touched Rs 11,800 Million during the last year. India is the largest producer of ginger in the world. It accounts for 65 percent of the world production of ginger. India contribution 86 percent of global spices production followed by China (4\%), 
Bangladesh (3\%), Pakistan (2\%), Turkey (2\%) and Nepal (1\%) (Spices Board of India 201314). In 2013-14 the total spices area was 3 , 3163 ha and ginger occupied $4.20 \%$ area to the area of total spices. Chhattisgarh is an agricultural chief land and due to large production of rice, it is known as the 'rice bowl'. The total area under spice in Chhattisgarh state was 91115 hectares. Ginger is being cultivated in 10662 hectares and their production is 119159 metric tons. Bilaspur district is in second position with report to the production of 13173 metric tons. Looking to the importance of ginger cultivation a present study work has been undertaken with following specific objectives:

\section{Materials and Methods}

The present study is conducted in Gaurela and Pendra blocks of Bilaspur district of Chhattisgarh state. Accordingly ten villages are selected. From these noticed villages of ginger cultivation, 5 villages from each sampled blocks were taken randomly viz., Tendumuda, Dhanauli, Lalpur, Pakariya and Korja villages for Gaurella block and Patgawa, Bacharwar, Latkoni, Kotmi-Kalan and Amarpur for Pendra block. Thus in all 50 farmers was selected randomly. After that ginger growers were categorized into small (1 $\leq 2 \mathrm{ha})$, medium $(2 \leq 4 \mathrm{ha})$, and large ( $\leq 4 \mathrm{ha})$. The study comprised of small (25), medium (20) and large (5). The Primary data are collected from the farmers through personal interview with the help of well-prepared schedule and questionnaire.

\section{Analytical tools}

\section{Computation of compound growth rate}

To compute the growth rate of area, production and productivity major spices of state and district the exponential function was used, which is as follows:
$\mathrm{Y}=\mathrm{A} \mathrm{B}^{\mathrm{t}}$

The estimated form of function as under:

$\log \mathrm{Y}=\log \mathrm{A}+\mathrm{t} \log \mathrm{B}$

Assuming as:

$\log \mathrm{Y}=\mathrm{Y}$

$\log \mathrm{A}=\mathrm{a}$

$\log B=b$

We get,

$Y=a+b t(t=1,2,3 \ldots \ldots \ldots n)$

After regression analysis we got value of a and b

$$
\begin{aligned}
& \mathrm{a}=\text { Constant } \\
& \mathrm{b}=\text { Coefficient }
\end{aligned}
$$

As,

$\mathrm{b}=1+\mathrm{r}$

Hence,

$$
\begin{aligned}
& r=b-1 \\
& r=\text { Compound growth rate } \\
& =(\text { antilog of } b-1) * 100 \\
& t=\text { Time variable }(t=1,2,3 \ldots \ldots \ldots . n) \\
& b=\text { coefficient of Regression. } \\
& Y=\quad \text { Index number }
\end{aligned}
$$$$
\text { area/production/productivity of spices. }
$$

\section{Cost of cultivation of ginger}

To estimate the cost of cultivation of ginger crop whole cost is divided in to two heads i.e. variable cost and fixed cost. The various cost components like human labour, bullock and machine power, manure and fertilizer, seed, irrigation, plant protection material and chemicals are taken in to consideration in order to work out the per hectare variable cost 
of cultivation. The interest on working capital involved in the cultivation is also computed at the prevailing rate of interest.

The cost of cultivation is estimated by using simple mathematical analysis.

To work out the cost of cultivation standard method of will be adopted. This includes cost $-\mathrm{A}$, cost - B and cost - C.

Cost A1: Consist of following 16 items of costs:-

Value of hired human labour (permanent \& casual)

Value of owned bullock labour

Value of hired bullock labour

Hired machinery charged

Value of fertilizers

Value of manure (produced on farm and purchased)

Value of seed (both farm-produced and purchased)

Value of insecticides and fungicides.

Irrigation charges (both of the owned \& owned and hired tube wells, pumping sets etc.)

Canal-water charges

Land revenue, cesses and other taxes

Depreciation on farm implements (both bullock drawn \& worked with human labour)

Depreciation on farm building, farm machinery.
Interest on the working capital.

Miscellaneous expenses (wages of artisans, and repairs to small farm implements)

Cost $\mathrm{A} 2=$ Cost $\mathrm{A} 1+$ Rent paid for Leased in Land.

Cost $\mathrm{B} 1=$ Cost $\mathrm{A} 1+$ Interest on value of Owned Capital assets (excluding land)

Cost $\mathrm{B} 2=$ Cost $\mathrm{B} 1+$ rental value of owned land (land revenue) and rent paid for leased-in land.

Cost $\mathrm{C} 1=$ Cost $\mathrm{B} 1+$ Imputed value of family labour.

Cost $\mathrm{C} 2=$ Cost $\mathrm{B} 2+$ Imputed value of family labour.

Cost $\mathrm{C} 3=$ Cost $\mathrm{C} 2+$ Value of management input at $10 \%$ of Cost C2.

Income over cost $A_{1}=$ Output Value - Cost $\mathrm{A}_{1}$

Income over cost $\mathrm{A}_{2}=$ Output Value $-\operatorname{Cost} \mathrm{A}_{2}$ Income over $\operatorname{cost} \mathrm{B}_{2}=$ Output Value $-\operatorname{Cost} \mathrm{B}_{1}$

Income over cost $\mathrm{B}_{2}=$ Output Value $-\operatorname{Cost} \mathrm{B}_{2}$

Income over $\operatorname{cost} \mathrm{C}_{1}=$ Output Value $-\operatorname{Cost} \mathrm{C}_{1}$

Income over cost $\mathrm{C}_{2}=$ Output Value $-\operatorname{Cost} \mathrm{C}_{2}$

Income over cost $\mathrm{C}_{3}=$ Output Value $-\operatorname{Cost} \mathrm{C}_{3}$

\section{Results and Discussion}

Growth rate in area and production was found positively significant at 5\% level of $\mathrm{t}$ distribution in both Bilaspur district and Chhattisgarh state but productivity of Bilaspur district found non- significant and 
Chhattisgarh state found negatively nonsignificant (Table 1).

\section{Cost of cultivation}

The total cost of cultivation per hectare of ginger was higher on large farms as compared to small and medium farms. That indicates the overall per hectare cost of cultivation of ginger worked out to Rs. 106368.20. The cost of cultivation in case of large farms was higher Rs. 112596.81 as compared to small, Rs. 91897.36 and Rs. 101347.74 at medium farms. Dewangan (2010) was found in his work the overall cost of cultivation of ginger Rs/ha 70774.77 (Table 2).

\section{Yield and profitability in ginger cultivation}

The empirical finding reveals that overall yield of ginger was found to be $118.84 \mathrm{q} / \mathrm{ha}$ at large farms followed by medium farms (102.32 q/ha) and small (83.48 q/ha). The estimated yield at sample farms was far below to yield of recommended package of practices of $200 \mathrm{q} / \mathrm{ha}$ to $250 \mathrm{q} / \mathrm{ha}$. The average of price of ginger sold by sample farms in study area was Rs/q 3600.45 (Table 3).

Overall, gross return obtained by sample farmers was Rs/ha 392123.11. Gross return from sample farms was increasing with increase in the farm size, which was the maximum at large farms Rs/ha 427877.48, followed by medium farms (Rs/ha 368398.04) and (Rs/ha 300565.57) at small farms respectively.

It is observed that total cost of cultivation in ginger was accounted to be Rs/ha 106368.20, irrespective to the farm size. The cost of cultivation of ginger was vary from Rs/ha 91897.36 at small farms to Rs/ha 112596.81 at large farms.

Overall obtained net return in ginger cultivation at sample farms Rs/ha 285754.92 which was noticed the maximum Rs/ha 315280.67 at large farms followed by medium farms (Rs/ha 1267050.30) and small farms (Rs/ha 208668.21).

The benefit over the cost in ginger was obtained to be 2.67, which varied from 2.27 to 2.80 among the farms. Bera and Moktan (2006) found in his research estimated net return of 20 ginger growers was Rs/acre 22245.05 and benefit-cost ratio 2.21.

The cost on one quintal production of ginger was found to be Rs/q 983.01. It is important to note that scale to economy was operated in cost of production in ginger, which was registered Rs/q 1100.83 at small farms, Rs/ha 990.50 at medium farms and 947.46 at large farms. Dewangan (2010) was found in his study cost of production of one ginger quintal Rs/q 1897.16.

Table.1 Growth rate in area, production and productivity of ginger

\begin{tabular}{|c|c|c|c|c|}
\hline S. No. & \multicolumn{1}{|c|}{ Region } & \multicolumn{3}{|c|}{ Compound growth rate (\%) } \\
\hline & & Area & Production & Productivity \\
\hline 1. & Bilaspur district & $23.35^{*}$ & $27.23 *$ & 3.17 \\
\hline 2. & Chhattisgarh state & $13.50^{*}$ & $9.23 *$ & -3.76 \\
\hline
\end{tabular}

Note: $* 5 \%$ probability level of $\mathrm{t}-$ distribution 
Table.2 Summarization of cost in ginger production

\begin{tabular}{|c|c|c|c|c|c|}
\hline \multirow{3}{*}{ S.No. } & \multirow{3}{*}{ Particulars } & & & & \multirow{2}{*}{$\begin{array}{l}\text { (Rs/ha) } \\
\text { Overall }\end{array}$} \\
\hline & & \multicolumn{3}{|c|}{ Farm size } & \\
\hline & & Small & Medium & Large & Overall \\
\hline I. & Variable cost & & & & \\
\hline $\mathbf{A}$ & Input Materials Cost & $\begin{array}{c}61318.89 \\
(66.73)\end{array}$ & $\begin{array}{l}69376.78 \\
(68.45)\end{array}$ & $\begin{array}{c}78179.98 \\
(69.43)\end{array}$ & $\begin{array}{c}73201.07 \\
(68.80)\end{array}$ \\
\hline B & Human labour Cost & $\begin{array}{c}13739.28 \\
(14.95)\end{array}$ & $\begin{array}{c}14347.73 \\
(14.16)\end{array}$ & $\begin{array}{c}15378.00 \\
(13.66)\end{array}$ & $\begin{array}{c}14848.13 \\
(14.00)\end{array}$ \\
\hline C. & Bullock Power & $1400.00(1.52)$ & $\begin{array}{c}1000.00 \\
(0.99)\end{array}$ & $\begin{array}{l}600.00 \\
(0.53)\end{array}$ & $\begin{array}{l}831.58 \\
(0.80)\end{array}$ \\
\hline D. & Machine Power & $1500.00(1.63)$ & $\begin{array}{c}2400.00 \\
(2.37)\end{array}$ & $\begin{array}{l}3000.00 \\
(2.66)\end{array}$ & $\begin{array}{c}2605.26 \\
(2.40)\end{array}$ \\
\hline \multirow[t]{2}{*}{ E. } & $\begin{array}{l}\text { Interest on working } \\
\text { capital }\end{array}$ & $\begin{array}{l}338.67 \\
(0.37)\end{array}$ & $\begin{array}{l}409.20 \\
(0.40)\end{array}$ & $\begin{array}{l}467.48 \\
(0.42)\end{array}$ & $\begin{array}{l}431.81 \\
(0.40)\end{array}$ \\
\hline & Total variable Cost & $\begin{array}{c}\mathbf{7 8 2 9 6 . 8 4} \\
(85.20)\end{array}$ & $\begin{array}{c}87533.71 \\
(86.37)\end{array}$ & $\begin{array}{c}97625.46 \\
(86.70)\end{array}$ & $\begin{array}{c}91917.85 \\
(86.40)\end{array}$ \\
\hline II. & Fixed Cost & & & & \\
\hline 1 & Depreciation & $\begin{array}{l}352.11 \\
(0.38)\end{array}$ & $\begin{array}{l}546.21 \\
(0.54)\end{array}$ & $\begin{array}{c}1598.32 \\
(1.42)\end{array}$ & $\begin{array}{c}1124.68 \\
(1.10)\end{array}$ \\
\hline 2 & Land Revenue & $\begin{array}{c}12 \\
(0.01)\end{array}$ & $\begin{array}{c}12 \\
(0.01)\end{array}$ & $\begin{array}{c}12 \\
(0.01)\end{array}$ & $\begin{array}{c}12 \\
(0.00)\end{array}$ \\
\hline 3 & $\begin{array}{l}\text { Rental Value of Owned } \\
\text { Land }\end{array}$ & $12000(13.06)$ & $\begin{array}{c}12000 \\
(11.84)\end{array}$ & $\begin{array}{c}12000 \\
(10.66)\end{array}$ & $\begin{array}{c}12000 \\
(11.30)\end{array}$ \\
\hline \multirow[t]{3}{*}{4} & Interest on Fixed Capital & $1236.41(1.35)$ & $\begin{array}{l}1255.821 \\
(1.24)\end{array}$ & $\begin{array}{c}1361.03 \\
(1.21)\end{array}$ & $\begin{array}{c}1313.66 \\
(1.20)\end{array}$ \\
\hline & Total Fixed Cost & $\begin{array}{c}13600.52 \\
(14.80)\end{array}$ & $\begin{array}{c}13814.03 \\
(13.63)\end{array}$ & $\begin{array}{c}14971.35 \\
(13.30)\end{array}$ & $\begin{array}{c}14450.35 \\
(13.60)\end{array}$ \\
\hline & Total Cost & $91897.36(100)$ & $\begin{array}{l}101347.74 \\
(100)\end{array}$ & $\begin{array}{l}112596.81 \\
(100)\end{array}$ & $\begin{array}{c}106368.20 \\
(100)\end{array}$ \\
\hline
\end{tabular}

Note: Figure in parenthesis percentage to total cost of cultivation.

Table.3 Yield and profitability in ginger cultivation

\begin{tabular}{|c|c|c|c|c|c|}
\hline & & & & & (Rs/ha) \\
\hline \multirow[t]{2}{*}{ S. No. } & \multirow[t]{2}{*}{ Particulars } & \multicolumn{3}{|c|}{ Farm Size } & Overall \\
\hline & & Small & Medium & Large & \\
\hline \multirow[t]{2}{*}{1} & Yield (q/ha) & 83.48 & 102.32 & 118.84 & 108.91 \\
\hline & $\begin{array}{l}\text { Cost of } \\
\text { cultivation(Rs/ha) }\end{array}$ & 91897.36 & 101347.74 & 112596.81 & 106368.20 \\
\hline 3 & Gross returns (Rs/ha) & 300565.57 & 368398.04 & 427877.48 & 392123.11 \\
\hline 4 & Price (Rs/qtl) & 3600.45 & 3600.45 & 3600.45 & 3600.45 \\
\hline 5 & Net returns (Rs/ha) & 208668.21 & 267050.30 & 315280.67 & 285754.92 \\
\hline 6 & $\begin{array}{l}\text { Cost of production } \\
\text { (Rs/qtl) }\end{array}$ & 1100.83 & 990.50 & 947.47 & 983.01 \\
\hline 7 & Input output ratio & $1: 3.27$ & $1: 3.63$ & $1: 3.80$ & $1: 3.67$ \\
\hline 8. & B.C ratio & 2.27 & 2.63 & 2.80 & 2.67 \\
\hline
\end{tabular}

Note: The prevailing market rate of ginger was Rs/q 3600.45. 
Table.4 Disposal pattern of ginger in sample farms

\begin{tabular}{|c|l|c|c|c|c|}
\hline & \multirow{2}{*}{ S.No. } & \multicolumn{1}{|c|}{ Farticular } & \multicolumn{4}{|c|}{ Farms) } & Overall \\
& & Small & Medium & Large & \\
\hline $\mathbf{1}$ & Total Quantity Produced & 5.00 & 10.23 & 26.14 & 18.62 \\
& & $(100)$ & $(100)$ & $(100)$ & $(100)$ \\
\hline $\mathbf{2}$ & Quantity Retained For The & 0.20 & 0.35 & 0.40 & 0.36 \\
& Seed purpose & $(4.00)$ & $(3.42)$ & $(1.53)$ & $(1.93)$ \\
\hline $\mathbf{3}$ & Quantity paid for wages & 0.18 & 0.22 & 0.24 & 0.23 \\
& & $(3.60)$ & $(2.15)$ & $(0.92)$ & $(1.24)$ \\
\hline $\mathbf{4}$ & Quantity used for home & 0.15 & 0.17 & 0.22 & 0.20 \\
& & $(3.00)$ & $(1.66)$ & $(0.84)$ & $(1.07)$ \\
\hline $\mathbf{5}$ & Total Quantity Utilized & 0.53 & 0.74 & 0.86 & 0.78 \\
& & $(10.60)$ & $(7.23)$ & $(3.29)$ & $(4.19)$ \\
\hline $\mathbf{6}$ & Marketable surplus & 4.47 & 9.49 & 25.28 & 17.84 \\
& & $(89.40)$ & $(92.49)$ & $(96.71)$ & $(95.81)$ \\
\hline
\end{tabular}

Note: Figure in parenthesis total quantity produced.

\section{Channel - I}
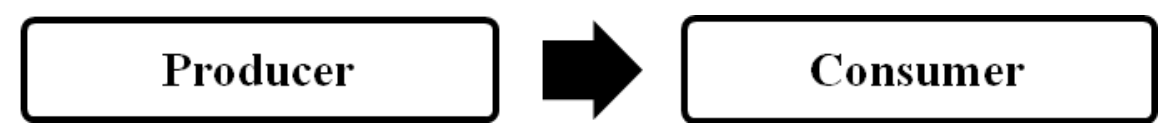

\section{Channel: - II}

\section{Producer}

\section{Itinerant (middle man)}

\section{Consumer}

\section{Marketing channel in ginger}

The study was identify that, there were two marketing channels prevailed in marketing of ginger which are as under:

Dewangan (2010) was found in his study there were three marketing channels for the marketing of major ginger, which are:

Channel-I: Producer- Consumer. Channel-II: Producer- Commission agent/ RetailerConsumer. Channel-III: ProducerShopkeeper-Consumer.

\section{Disposal pattern of ginger}

The study found that out of total production of ginger $18.62 \mathrm{q} / \mathrm{farm}, 95.81$ percent was for marketable surplus and remaining quantity was used for wage payment $(1.24 \%)$, and home consumption $(0.20 \%)$, irrespective to the farm size. It can be inferred that very negligible quantity was used for owned and payment others. However, quantity was for owned and payment to others than that of ginger was found to be increasing with farm size, which the maximum at large farm and found to be $25.28 \mathrm{q} /$ farm followed by medium 
farms $(9.49 q /$ farm $)$ and small farms (4.47q/farm), respectively. Dewangan found in his study more than $85 \%$ marketable surplus was observed in all the major spices in different size groups of farmers.

\section{Constants in production and marketing of spices}

The major constraints in production of ginger were highly infestation of insects, pests and diseases which was reported by $68 \%$ spice growers. Another major problem was illiterate by ginger growers on non-availability of soil testing facilities, which was reported by $42 \%$ farmers. Third major problem was elucidated by farmers on lack of adequate training facility for cultivation of ginger, which was reported by $40 \%$ farmers.

The farmers were elucidated the major problems in marketing of ginger lack of storage facility for grading and standardization of ginger, lack of post-harvest management, lack of transportation facilities and lack of organized which was reported by $50 \%, 46 \%$ and $38 \%$ farmers.

\section{References}

Anonymous, Database of Deputy Directorate of Horticulture Bilaspur Chattisgarh. 2013-14.

Anonymous, Database of Directorate of Economics and Statistics Chhattisgarh 2014-15.

Anonymous, Database of District statistical booklet 2014-15. District statistical office Bilaspur.

Bera, B.K. and Moktan, M.W. 2006. Economics of ginger cultivation in the Hill Region of West Bengal. Journal of crop and weed 2(2): 11-13.

Dewangan, Omprakash 2010. An economic analysis of production and marketing of major spices in Bilaspur district of chhattisgarh, M.Sc. (Agri) Thesis submitted to, Indira Gandhi Agricultural University Raipur.

\section{How to cite this article:}

Dilip Kumar Sonwani, A.K. Koshta and Birendra Tigga. 2018. An Economic Analysis of Production and Marketing of Ginger in Bilaspur District of Chhattisgarh, India. Int.J.Curr.Microbiol.App.Sci. 7(01): 2195-2201. doi: https://doi.org/10.20546/ijcmas.2018.701.264 